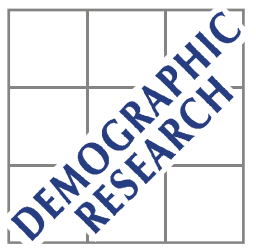

Demographic Research a free, expedited, online journal

of peer-reviewed research and commentary in the population sciences published by the Max Planck Institute for Demographic Research

Konrad-Zuse Str. 1, D-18057 Rostock · GERMANY

www.demographic-research.org

DEMOGRAPHIC RESEARCH

VOLUME 24, ARTICLE 10 PAGES 225-250

PUBLISHED 02 FEBRUARY 2011

http://www.demographic-research.org/Volumes/Vol24/10/

DOI: $10.4054 /$ DemRes.2011.24.10

Reflexion

\title{
Should governments in Europe be more aggressive in pushing for gender equality to raise fertility? The second "NO"
}

\section{Gerda Neyer}

This publication is part of the Special Collection "Rostock debate on demographic change", organized by Guest Editor Laura Bernardi.

(C) 2011 Gerda Neyer.

This open-access work is published under the terms of the Creative Commons Attribution NonCommercial License 2.0 Germany, which permits use, reproduction \& distribution in any medium for non-commercial purposes, provided the original author(s) and source are given credit.

See http:// creativecommons.org/licenses/by-nc/2.0/de/ 


\section{Table of Contents}

1 Introduction 226

2 "No" to the goal of raising fertility, or why we should resist 227 political endeavors to raise fertility

2.1 The Eurocentrist or colonialist myth 228

$\begin{array}{lll}2.2 & \text { The protectionist myth } & 230\end{array}$

2.3 The myth of welfare conservatism 233

2.4 The myth of ethnic homogeneity 234

3 "No" to the method - "No" to more aggressive fertility-targeting 237 politics

$4 \quad$ "No" to the means - "No" to using gender equality policies to 239 increase fertility

5 Conclusion 244

6 Acknowledgments $\quad 244$

$\begin{array}{ll}\text { References } & 245\end{array}$ 


\title{
Should governments in Europe be more aggressive in pushing for gender equality to raise fertility? The second "NO" 1
}

\author{
Gerda Neyer ${ }^{2}$
}

\begin{abstract}
This paper argues against the suggestion that governments should push for gender equality more aggressively in order to raise fertility. The paper presents a threefold "no" to this proposal. It takes issue with the goal of raising fertility, arguing that the claims that fertility must be increased are based on myths. It rejects a more aggressive pursuit of gender equality for demographic purposes, maintaining that this method preserves inequality. It warns against using gender equality for fertility purposes, stating that this narrows the realm of gender equality.

The paper is based on a debate held at the Max Planck Institute for Demographic Research in Rostock, at which the author was asked to argue against the gender equality-fertility proposal. The other participants in the debate were Laurent Toulemon ("yes"), Dimiter Philipov ("no"), and Livia Oláh (“yes").
\end{abstract}

\footnotetext{
${ }^{1}$ This is the second of two "no" positions taken from the "Rostock Debate on Demographic Change" held at the Max Planck Institute for Demographic Research on 21 February 2006.

${ }^{2}$ Stockholm University, Demography Unit. E-mail: gerda.neyer@sociology.su.se
} 


\section{Introduction}

Women have struggled for gender equality for almost 220 years ${ }^{3}$, but Europe is still far from having achieved it. Women in the European Union now clearly outperform men in educational attainment; there are more women than men among the graduates of secondary- and tertiary-level educational institutions, and among participants in lifelong learning programs. Nevertheless, women are still less likely than men to attain decision-making positions in academia, in politics, and in economic life. Women still earn less than men, have lower employment rates and higher unemployment rates, are more likely to work part-time, are at higher risk of poverty, and still do most of the domestic and care work (Commission of the European Communities 2005a). Progress towards gender equality has varied greatly across time, across countries, and across policy areas. Successes in reducing gender gaps have often been followed by backlashes, and increasing gender equality in some areas has been accompanied by growing gender inequality in other areas.

The low fertility rates in Europe have given another twist to gender equality policies. In recent years, we have observed a general shift in policy focus and efforts, namely, from gender equality policies to family policies. Making private matters an issue of public policy has been a central goal of European feminist movements since the 1960 s, but the shift in public attention to family policies has also narrowed the range of gender issues to private relationships. Given this turn in the content of gender equality discussions, and given the still unfulfilled hopes for genuine gender equality, should we not answer "yes" to the question posed in this debate, grasp the opportunity for more active gender equality policies that has opened up, and refrain from asking why and how we will get (more) gender equality? ${ }^{4}$ I maintain that we should resist these temptations, and respond to the question with a threefold "no":

"No" to the goal, which is to raise fertility.

"No" to the method, which is to push for population policies more aggressively.

"No" to the means, which are to use gender equality policies to promote fertility issues. ${ }^{5}$ Here is why I go in for this triple "no."

\footnotetext{
${ }^{3}$ Two texts, published at the time of the French Revolution, are usually regarded as indicators of the beginning of women's struggle for equality, namely Mary Wollstonecraft's, $A$ Vindication of the Rights of Woman (1792) and Olympe de Gouges', Déclaration des droits de la femme et de la citoyenne (1791).

${ }^{4}$ This was the advice that the former Austrian chancellor Bruno Kreisky gave feminists in 1978, when he countered their criticism that the appointment of four additional women to his government primarily served the interests of his own party.

${ }^{5}$ Note that these three issues are interlinked, first through the way in which the question is posed. Second, if we reject the aim of raising fertility, we do not need to talk about the methods and the means. Third, gender policies are population policies in that they seek to regulate the relationship between women and men. For the
} 


\section{2. "No" to the goal of raising fertility, or why we should resist political endeavors to raise fertility}

Any claim that fertility should be raised rests on three assumptions: first, that fertility levels are too low; second, that low fertility levels will have negative consequences for Europe; and, third, that policies can actually raise fertility. However, neither an assessment that fertility levels are too low, nor the conclusion that this will be detrimental for Europe, describe a demographic reality or a demographically determined future; instead, these assumptions construct them. As Laurent Toulemon has pointed out in this debate, demographic measures are subject to interpretation, and are not immutable facts of reality. It is thus a matter of convention whether fertility is regarded as "low" or "high" or "normal." In other words, it is demographers, politicians, the media, or other groups of people or public institutions who produce the perception that fertility levels are too "low" or too "high" or "normal." Likewise, it is they who construct the social, economic, and political consequences of fertility levels by transforming demographic measures into ostensibly negative outcomes for the future. ${ }^{6}$ It is therefore necessary to deconstruct the low-fertility hype, to look at the images which dominate this discourse, and to uncover the aims of those driving the discussion.

The current discourse on "low" fertility and its consequences is dominated by perceptions about population aging. In many ways, this discourse has taken on gerontophobic features: population aging is seen as a major cause of a societal development which is deemed to be unfavorable, problematic, and even detrimental for Europe (Commission of the European Communities 2005b; Schirrmacher 2004). Within a frame of thinking which looks at the future prospects of Europe solely from a population perspective, and which reduces future social issues to population issues, raising fertility may indeed appear to be the main or even only feasible remedy for population aging, the social problems assumed to be incurred by it, and the presumed demise of Europe. I will present four arguments which are usually made in favor of increasing fertility in such discourses - and I do so in order to maintain that such claims are based on myths; that is, on widespread beliefs intended to explain the ostensible consequences of low fertility and to underscore the need to avoid it. The myths I want to discuss here are Eurocentrism and colonialism, labor market protectionism, welfare

sake of the debate, however, I organize my arguments along the three proposed lines, even though it will not always be possible to distinguish them strictly from each other.

${ }^{6}$ As Hodgson (1983) and Greenhalgh (2003) have shown, demographers profit from such constructions of the demographic present and its future consequences, because it draws public and political interest to demographic issues and increases demographers' opportunities to get research funding. 
conservatism, and ethnic homogeneity. Once we have realized that the campaign to raise fertility is based on myths, there is no further need to call for gender equality policies or for any other policies as a means of raising fertility, because the very foundation on which the calls to raise fertility are based will have vanished. I will therefore devote somewhat more space to the exposure of fertility-raising arguments as myths than to the discussion of why we should not use gender equality policies to achieve fertility matters.

\subsection{The Eurocentrist or colonialist myth}

It is often asserted that the low fertility levels in developed countries and the high fertility levels in developing countries will lead to an imbalance between these groups of countries in population size and population structure. According to proponents of this view, this demographic imbalance will put the developed countries at a global disadvantage (Birg 2001:15) brought on by the drop in productivity in aging societies (see Skirbekk 2003 for a literature review; also Skirbekk 2005). These researchers assume that younger people are more creative and have greater cognitive abilities than older people; they therefore argue that persistently low fertility and increasing longevity will lower the capacity for innovation and will curb productivity in aging populations. ${ }^{7}$ Since Europe is the only continent with long-term low fertility, many fear that Europe in particular will suffer from the lack of innovation due to population aging, while continents with high fertility will prosper due to their large numbers of young people and their creative force.

This image of youth as the driving force of innovation, productivity, and future prosperity contrasts with other authors' dismal assessments of the youth bulge in developing countries. Countries with a large share of young people - and, in particular, countries with a large share of (unemployed) young males - are considered to be more at risk of political violence and of armed internal conflicts, terrorism, and riots (Urdal 2006). Should such developments occur, they may have repercussions for Europe. It is feared that population decline, population aging, the shrinking number of young people, and the accompanying decrease in innovative potential will restrain the capacity of Europe's military to intervene in conflict situations, and will therefore limit Europe's ability to control and resolve such conflicts (Demeny 2003).

\footnotetext{
${ }^{7}$ For a counter-argument, see Lindh (2005), who argues that comparisons between older and younger workers are biased due to the selectivity in mobility between occupations.
} 
This type of argument rests on two suppositions which are of interest for our discussion: first, that creativity and technological advancement are primarily tied to age; and, second, the idea of Europe's superiority. Let us address these suppositions.

First, we should first note that being young does not alone assure creativity or scientific advancement. Such features rather depend on the resources and the opportunities available to an individual or to a society. They depend on favorable economic, social, and political circumstances, which provide a person or a society with the freedom to develop existing potentials (Sen 1992; see also Keyfitz 1992). By focusing solely on age, researchers give priority to biology and turn a blind eye to the fundamental inequalities in access to resources, opportunities, and capabilities between countries and between individuals. As demographers, we should know that most countries with very high fertility are among the poorest countries in the world. In general, their young people - women even more so than men - hardly possess the resources or opportunities that would enable them to compete on an equal footing with youths from low-fertility European countries in a technological race that is supposed to be initiated by demographic factors. As gender-sensitive researchers, we should be particularly wary of any attempts to brush aside economic and social inequality, and to declare any kind of biology destiny. Remember that women's "nature" not least their reproductive capacity, has long been used to question women's creativity and their intellectual and technological potential, and to refuse to accept them as equals. Similarly, to regard the youth of developing countries as a potential threat to Europe's technological lead reveals that we cling to a desire to maintain (global) inequality, and are reluctant to allow for equality.

Second, this leads us to the idea that Europe's superiority is at stake due to its low fertility. Europe is seen as falling behind and sliding into a disadvantageous position relative to the rest of the globe, while developing countries are assumed to be thriving due to their higher fertility and their larger share of young people. Such reasoning has long underpinned the West's efforts to lower fertility in developing countries. Ostensibly - and, perhaps, genuinely - those advancing these arguments have sought to prevent the negative local effects of growing populations in these countries. Yet some politicians, commentators, and researchers have come to perceive population trends as a threat to world stability and to the supremacy of the West, and for this reason have called for lowering fertility rates in high-fertility countries (see, e.g.: Ehrlich 1968). Population policies have been regarded as a means to maintain control not only over these countries' population development, but over their development in general (Connelly 2008). As demographers, we cannot feel proud that the presumption of a detrimental population development has long formed the core argument for 
implementing population policies, and that in many countries it even has been an important element in efforts to establish demography as a scientific discipline. ${ }^{8}$

The attempts to raise fertility in low-fertility Western countries, and to lower fertility in high-fertility non-Western countries, can therefore not be separated from each other in the intellectual discourse. They are part and parcel of the same Eurocentric thinking, and of the same colonialist attitude. The argument that low fertility will put Europe at a technological and intellectual disadvantage essentially strives to maintain a hierarchical world order with Europe at the top. This kind of thinking refuses to accept that developing countries can catch up with Europe or might even overtake Europe. Claiming superiority for Europe has always formed the core of colonialism and Eurocentrism, and the plea for higher European fertility is still deeply rooted in it.

\subsection{The protectionist myth}

In many countries, there are public concerns that low fertility will lead to economic decline. Several arguments are marshaled to underline the economic threat posed by low fertility. Many studies have argued that economic growth is linked to population growth (Lindh and Malmberg 1999). Many therefore conclude that, since belowreplacement fertility will lead to population decline, it will also bring about economic decline. Penciling out this reasoning, people argue that low fertility rates (and increasing longevity) reduce the share of the population who are of working age. This is expected to depress the factors which boost economic growth: namely, labor supply, productivity, earnings, and savings (Bloom, Canning, and Fink 2008:15) and to lead to negative or at least slower economic growth (Bloom, Canning, and Fink 2008:16, 20; Bloom et al. 2010; Lindh and Malmberg 2009:177; Feyrer 2007). Part of this picture is that long-term low fertility is seen as changing the age structure of the labor force toward a sub-optimal age composition, which is assumed to strain economic sectors that need a young workforce, to lower productivity in general, and to hamper economic growth (Lindh and Malmberg 2009; Prskawetz and Lindh 2007). Companies that need a young workforce may then direct their investments to countries with young technologically skilled workers (McDonald 2008), which aggravates the economic effects of a sub-optimal age composition in low-fertility countries.

Unfortunately, proposals which call for a boost in fertility to tackle such developments are bound to end in failure. There are several reasons for this assessment. First, calls for a fertility increase are based on the assumption of an optimal population

${ }^{8}$ See Hodgson (1983); Greenhalgh (2003); Caldwell and Caldwell (1986); Szreter (1993). 
distribution, or of an optimal age structure of the working population at the outset. As outlined above, such an assumption is subject to convention; it may follow from theoretical requirements, or be deduced from empirical results. In either case, the concept of an optimal current age balance of the working population (or of any optimal population balance) cannot be separated from the societal and economic circumstances and the scientific standards which determine what is regarded as an optimal or suboptimal population balance. It may well be that what is considered sub-optimal today may be optimal in the future. Having a large cohort of young people when the "optimal age structure" demands a small one aggravates the labor market opportunities of this cohort, and increases unemployment among these young people. This may in turn have repercussions for economic performance, since higher unemployment reduces income and consumption levels (Easterlin 1978). In conservative welfare states which directly or indirectly support mothers' retreat from employment, higher fertility might even reduce the share of women in the labor market, thus creating a sub-optimal age structure among female workers, which again may have negative economic consequences of its own.

Second, the suggestion that we should counteract the ostensibly adverse labor market effects of population imbalance by increasing fertility represents a clear case of thinking within closed systems. This position rests on the assumption that, if low fertility causes population imbalance, which in turn causes economic decline, fertility must be increased in order to restore an optimal population balance, which then will prevent or reverse economic decline. However, this logic establishes a mechanistic linkage between demography and economics; a connection which does not hold in practice. It ignores the fact that many features of economic development may be independent of demographic issues. It also ignores the possibility that economic development may influence the structure of the working population. For example, it has become common practice in many countries to tackle high unemployment by promoting early retirement. This reduces the share of workers aged 50 to 64 , even though studies have shown that workers in this age group have a positive impact on labor productivity and economic growth (Lindh and Malmberg 1999). Moreover, there is no way to foresee accurately economic development in the long run (and not even in the short run, as recent sudden economic crises have taught us). Similarly, we cannot foretell the direction and dimension of technological and economic changes, and their effects on the working population; nor can we foresee the extent to which individuals will adapt to new work requirements. As Lindh (2005) puts it, productivity and economic growth are systemic properties, and depend on calculation; they are not the outcome of individual productivity or of any age-specific productivity distribution. With regard to the link between fertility increase and economic growth, we can state that the question of whether higher fertility will contribute to economic growth (in the long run) is not a 
question of whether there are more children, but rather of whether these children, once grown up, will have work or not (for only paid work is included in measures of productivity and economic growth). ${ }^{9}$ The latter depends largely on economic development, not on demographic development.

Those who propose an increase in fertility to tackle labor market issues also overlook the potential of the economic sector to adjust to population aging. It is as if the current demographic structure of the working population needs to be protected because it is assumed to be the only optimal one for economic prosperity. This reminds me of $19^{\text {th }}$-century male workers' petitions for legislation to prevent women from entering the labor market. Their advocacy of the protection of the then current sex structure of the labor market was based on fears of the adverse economic consequences of demographic change for themselves; in their case, of a feminization of the workforce. They sought to protect the labor market structure by maintaining its demographic structure. ${ }^{10} \mathrm{As}$ economic developments later demonstrated, demographic protectionism (implemented in many countries) ${ }^{11}$ could not prevent massive restructuring of economies and labor markets, including the expansion of female employment. Such restructuring of economies and labor markets led to economic expansion, while the postponement of change through protectionism did not. ${ }^{12}$ In brief, future labor market and economic issues cannot be settled by raising fertility, since more (or fewer) children will not protect us from the need to restructure markets in the face of globalization, aging, technological advancement, or other economically relevant developments. Preserving economic prosperity through higher fertility means relying on a myth, because its claims are based on an assumed connection between fertility and economic development that may not hold in the future. I therefore call appeals to increase fertility to maintain current economic growth the myth of protectionism.

\footnotetext{
${ }^{9}$ This is all provided the method of measuring productivity remains the same as it is now.

${ }^{10}$ Women were seen as a threat to male workers during the 19th century because women earned less than men did. They were more often employed in industrial production, which in itself constituted a fierce competition for many trades. As industrial workers women lacked the (moderate) social protection that trades offered; female work was regarded as undermining the economic security and social protection of male workers. Calls for legislation prohibiting women's employment were often an attempt to stop the further development of industrial production. (For the debates in different countries, see Wikander, Kessler-Harris, and Lewis 1995.)

${ }^{11}$ Many countries introduced prohibitive or protective measures for women in industry and large trades, such as a prohibition of female employment for specific branches (mining), specific time arrangements (night shift, maximal working hours), or for specific groups of women (mothers after childbirth and pregnant women). As outlined in the footnote above, such measures, however well-intentioned in principle, aimed in reality at protecting male employment in trade against industrial competition.

${ }^{12}$ This does not mean that I welcome the unconditional restructuring of economies and labor markets in the manner that $19^{\text {th }}$ century liberal capitalism did.
} 


\subsection{The myth of welfare conservatism}

Many researchers maintain that the European welfare states, and particularly their pension systems, will not be sustainable unless European countries increase their fertility. (See, for example, Bongaarts 2004; Lindh, Malmberg, and Palme 2005.) Some argue that population aging increases the number of pension recipients, and causes pension expenditures to rise to unsustainable levels (Bongaarts 2004). Others reason that the increasing share of older people will create a "gerontocracy," because population aging leads to an aging electorate, and older people are more likely than younger people to participate in elections, which gives them more political power. This will make it politically difficult to lower pension benefits or pass other measures which would affect the elderly negatively (Sanderson and Scherbov 2007). ${ }^{13}$ Higher fertility, it is argued, would counter these developments, since it would increase the number of young people, reduce the pensioner-worker ratio, and rejuvenate the constituency (Bongaarts 2004; van Parijs 1999). However, as outlined in connection with the other myths, an increase in fertility is not a feasible means to address population aging or to secure the welfare state for the future. Remaining fixated within the bounds of demography in seeking remedies to population aging will only block us off from thinking creatively about viable options for sustaining the welfare state and old-age security for all. Welfare states and pension systems vary considerably across Europe (Immergut, Anderson, and Schulze 2006). The pay-as-you-go pension systems in particular are seen as likely to be negatively affected by population aging. Such systems are financed through current workers' contributions. They are therefore more susceptible to influence from a growing number of pensioners and a shrinking number of contributors than are pension systems which do not solely depend on individual contributors. Pension systems in some countries are also associated with employment and family policies, and their economics have been influenced by early retirement policies (to reduce unemployment), various exemptions from contributions (e.g., lowerand upper-income boundaries for contributions, exemptions of certain types of income) or the contribution-free inclusion of various groups of the population in the pension system (e.g., non-working spouses; see Immergut, Anderson, and Schulze 2006). These examples show that it is the institutional design of the welfare system and of the social policies, as much as the demographic changes themselves, that account for the vulnerability of social security systems. The discussion of population aging and of welfare state sustainability should therefore focus on how to increase the number of contributors, change basic contribution arrangements, finance the welfare state in times

\footnotetext{
${ }^{13}$ For a more nuanced (counter-)argument, see Busemeyer, Goerres, and Weschle (2009); Lynch and Myrskylä (2009); Wilkoszewski and Muth (2009).
} 
of changing labor markets and changing population structure; or, more generally, on how to reform welfare systems so that they are demographically and economically sustainable in the future. Fertility increase is not a measure that in itself would make welfare state and pension systems more sustainable. A purely demographic solution would, rather, conserve potentially unsustainable welfare state structures. I therefore call the plea to increase fertility in order to maintain welfare state and pension systems the myth of conservatism.

\subsection{The myth of ethnic homogeneity}

Persistently low fertility, together with the prospects of population decline, a shrinking labor force, and an increasing old-age dependency ratio, have led many researchers to propose immigration as a compensatory measure for low birth numbers, and for a shortage of labor (Malmberg 2006). These suggestions aim at stabilizing or restoring a population structure that is seen as optimal for sustaining or enhancing Europe's economic performance, and for maintaining its labor market structure, its pension systems, and its welfare levels. In other words, within a stationary demographic framework, the only solution is seen as: if not births, then immigrants. Proposals to increase immigration in order to counteract a shortage of births and workers have drawn criticism from two sides.

On the one hand, the concept of replacement migration views migrants merely as an economic or demographic resource (and not as human beings with their own needs and individuality). It distinguishes (implicitly or explicitly) between wanted and unwanted migration and migrants. It assumes that migration streams can be planned and controlled. It pretends (and, indirectly, even proposes) that countries recruit precisely the migrants whom they need for precisely the time for which they need them, and that the in-migrants will behave - and, above all, reproduce - precisely in the ways needed to reach the perceived optimal population distribution in the immigration country. ${ }^{14}$

On the other hand, and this is the issue I want to focus on in this debate, some researchers have started to warn of the supposedly detrimental consequences of compensatory immigration (Coleman 2006a). It is argued that sustaining an optimal population structure would require a continuous inflow of migrants. This would "quickly replace the original population from its majority position" (Coleman 2006a:73) and "the receiving societies would rapidly cease to exist in any recognizable form" (ibid.). Even in the short run, continued immigration and the "numerical

\footnotetext{
${ }^{14}$ The "guest worker scheme" which dominated the immigration policies of Germany, Austria, and other European countries in the 1960s and 1970s, followed these assumptions. The scheme proved to be a failure.
} 
inferiority" (Coleman 2006b:403) of "the population of indigenous origin" (op.cit., 402) would fundamentally alter the character, physical appearance, culture, and identity of the population; and would disconnect the population from the history of the territory, from their values, and from their shared identity (Coleman 2006b:425, 426; Coleman 2009:472). Despite such changes, immigration would not solve the problem of aging. Raising fertility is therefore seen as a more efficient means against what are seen as dire prospects (Coleman 2006a:73, 87).

Such argumentation introduces a hierarchical distinction between "us," - i.e., the people of supposedly "indigenous origin" - and "others," i.e. all those who are declared not to be of this origin. It invokes the fear that too many "others" or too much "otherness" will undermine social cohesion, lead to the break-up of society, or even to the extinction of "us" as a people. However, the notion of "us" as a homogenous people, and of a cultural, religious, ethnic, national, or even genetic commonality among "us" are pure constructs, "imagined communities" (Anderson 1991) rooted in $19^{\text {th }}$ - and early $20^{\text {th }}$-century nationalist movements, with their attempts to create nation states by inducing and mobilizing feelings of distinction between "us" and "others" (ibid). The proclaimed homogeneity and distinct identity of Europe (or of any European country) does not hold in the face of Europe's centuries-long migration history and its history of changing national borders. Such assumptions are based on the "myth of common origin" and common belonging, and on the myth of a fixed and immutable unity and an alleged "sameness" (Yuval-Davis, Anthias, and Kofman 2005:516). Calls to increase fertility in order to balance any compensatory immigration and to preserve the cultural, ethnic, national, or genetic unity of "us" have their roots in this myth; and, moreover, constitute another of demography's various roles in constructing such fictions of unity. ${ }^{15}$ I therefore refer to the suggestion to increase fertility to maintain Europe's identity as the myth of ethnic homogeneity.

To sum up, I have delineated four myths that surround low fertility. They all have roots in a common overarching sequence of myths; namely, that fertility is too low, that low fertility will be detrimental to Europe, and that the only way to prevent Europe's demise is to raise fertility. To dispel these myths, let us briefly return to common measures of fertility. The perception that fertility is too low stems mostly from the use of the period TFR (Total Fertility Rate) in discourses on low fertility. Demographers know that the period TFR reflects the reproductive behavior of different groups of women at one particular point in time, and does not reflect women's reproductive

\footnotetext{
${ }^{15}$ In the second (1991) and subsequent editions of his book, "Imagined Communities," Anderson discusses the role which demography, in the form of the census, played in the construction of national identities and (nation-based) ethnic homogeneity. For an elaboration on the role of censuses in the construction of identities, see also Kertzer and Arel (2002).
} 
behavior over their life course. If we consider the latter, the CFR (Completed Cohort Fertility Rate) is the more relevant indicator; it provides a better measure for a country's long-term fertility level, and it is usually higher than the TFR. The current CFR of most European countries is between 1.8 and 2.0 (for women born in 1965) (Council of Europe 2006), and thus clearly above the level of 1.5, which for some demographers marks the threshold at which governments should take fertility-increasing actions (McDonald 2006a). The proposed fertility crisis and the doomsday consequences derived from it might therefore not be as severe as claimed.

Nevertheless, all appeals to increase fertility in order to prevent Europe's demise share an implicit assumption: namely, that policies can actually raise fertility. However, most demographers doubt that it is possible to increase fertility and to sustain it at the desired levels through the implementation of policies (e.g., Demeny 1986, 2003; Hoem 2008). Such attempts have been repeatedly undertaken, mostly by authoritarian regimes, ${ }^{16}$ and all have failed or have only had short-term effects.

This should make us wary, and we should ask ourselves the following questions: Why are we made to believe that fertility is too low, and that this situation will bring Europe down? Why should we divert our policy efforts towards increasing fertility, if this endeavor neither promises to be a success nor - as outlined in the discussion of the four myths above - contributes to solving pending social, economic, and demographic problems of contemporary (and future) Europe? Is the fertility discourse intended to hide these and other problems which Europe faces, and which might be much more difficult to address, let alone to find solutions for?

If we pose these or similar questions and challenge the myths of low fertility and all the other myths based on it, we will never end up proposing fertility-enhancing policies as a means to deal with current and future social, economic, demographic, cultural, and gender issues. Nor would we suggest that we use gender equality policies for such a purpose. Viewing fertility, social, economic, and gender developments not through the blurred vision of myths, but with the candid eyes of those who acknowledge that low fertility is constructed, we can only come up with one answer: "no" to any proposals for pro-natalist policies of any kind.

\footnotetext{
${ }^{16}$ Examples are Nazi Germany, which tried to promote Aryan motherhood; the former German Democratic Republic (GDR), which implemented a set of measures to increase fertility in the mid-1970s; communist Romania, which prohibited any kind of contraception and forbade abortion in the 1960s; and other countries in Eastern Europe during the communist regime (Frejka et al. 2008).
} 


\section{3. "No" to the method - "No" to more aggressive fertility-targeting politics}

Those who claim that fertility is too low and needs to be raised usually neglect to consider the gender implications of their proposal. As I mentioned above, the call to increase fertility targets women, because ultimately it is still women who make the decision about whether to have a child. The focus of these calls is, therefore, mainly the reproductive function of women. This confronts us with a contradiction from the onset: i.e., the gendered nature of the low-fertility discourse and the further reduction of the discourse to female reproduction undermine the promise of more gender equality.

Politically, people have focused on women and their reproductive potentials for various purposes, most notably to mobilize people for war and secession; for nationalistic, colonialist, or racist intentions; or to divert attention from political and economic problems (Yuval-Davis 1997; Gal and Kligman 2000). Births, female reproduction, women's "nature," and women's actual or presumed tasks in the family, in employment, and in society have also played major roles in the foundation and development of welfare policies, particularly of fertility-related policies, and of policies designed to enhance gender equality (Koven and Michel 1993; Skocpol 1992; Wikander, Kessler-Harris, and Lewis 1995). Following Yuval-Davis (1997), I want to point to three perceptions of women and female reproduction that have come up repeatedly in political contexts, and that are of importance for our topic:

First, women (and particularly mothers) have been portrayed as the cultural reproducers of the nation. They are perceived and are addressed as the ones who transmit to the next generation language, religion, values, beliefs, and political and moral attitudes. They have been seen as the ones who make the next generation into proper citizens, workers, or members of the respective national, ethnic, or religious group.

Second, women are regarded as the biological reproducers of society. The fact that they bear children has not only made them the prime objects of both pronatalist and antinatalist endeavors; it has also been a major element in denying women equal rights and equal treatment up to the present.

Third, women are seen as creators and maintainers of social solidarity and social cohesion. This is closely linked to the fact that it is usually women who provide most of the care for children, the sick, and the aged; and that care involves interpersonal relationships, connectedness, and social ties, which are often regarded as being in contrast to the dominant economic utility-maximizing rationality (Gilligan 1982).

There is a danger that such cultural, biological, and social perceptions concerning women are revived in current discussions of low fertility and in the recommendations to raise fertility. The resurgence of nationalistic, anti-immigrant, and fundamentalist 
religious movements, and the accompanying demographic discourses; as well as the political debates about the perceived shortfall in fertility among highly educated women, and the presumed negative consequences for society of this fertility gap in several European countries, are only the most visible parts of this development. The danger arises precisely from the fact that the low-fertility discourse does not address its gendered basis and aims, and thus maintains the risk of upholding, reinforcing, or reinventing distorted images of women, of reproduction, and of gender. ${ }^{17}$ Proclaiming that gender equality policies will raise fertility disguises the gendered nature of such a proposal even more than proclaiming overtly pronatalist policies would do. Following Mary Wollstonecraft, Carole Pateman (1989) argues that claims to equality based on (reproductive) differences can never lead to full equality; instead, they preserve the differences on which inequality is based. ${ }^{18}$ Calling for more gender equality in order to increase fertility does not tackle this fundamental equality-difference dilemma. A truly gender-equal perspective would have to question the absence of a gender debate in the myths surrounding low fertility and in the suggestions to reverse it. It would need to highlight the gender bias in fertility policies that are wrapped in promises of gender equality. Since this is not done, we must say "no" to using gender equality for fertilityincreasing aims.

There is one more aspect of the method promoted to increase fertility which we should strictly reject: namely, the call to push for gender equality more aggressively. The term "aggressiveness" evokes gendered images of masculinity vs. femininity, particularly because aggressiveness is often positively valued in men but negatively valued in women (Gilligan 1982). ${ }^{19}$ It recalls associations of hierarchical ordering; of violence, dominance, and oppression; of stricter law enforcement; and of the limitation of individual or collective rights. Aggressiveness demonstrates power, and it implies inequality, force, coercion, and control. All of these aspects are incompatible with gender equality. To achieve true gender equality in all aspects of social, economic, private, and political life, we need to strengthen democratic principles of participation,

${ }^{17}$ A recent example of the prevalence of distorted perceptions of female reproduction and its consequences was delivered by the former president of Harvard University, Lawrence H. Summers, who claimed in 2005 that innate differences between women and men, and in particular women's inclination to devote time to their children rather than to an 80-hours-per-week (sic!) paid work schedule explain why there are fewer women in top scientific and technological positions. On the images of women and gender in demographic discourses, see Watkins (1993), Presser (1997).

${ }^{18}$ Pateman refers to this as "Wollstonecraft's dilemma": She argues that neither claims based on (reproductive) differences between women and men nor claims which negate such differences can lead to full gender equality.

${ }^{19}$ This does not imply that men are (genuinely) more aggressive than women are. Much research has shown that such an assumption adheres to a false, ahistorical, and acultural gender polarization. For a recent debate on whether hormones nevertheless influence sex-specific behavior, see Udry $(2000,2001)$ and replies by Miller and Costello (2001), Kennelly, Merz, and Lorber (2001), and Risman (2001). 
recognition, and continual dialogue to ensure that greater gender equality for some groups of people and in some areas of public or private life does not lead to less (gender) equality for other groups of people or in other areas of public or private life. Therefore, we must say "no" to the method of pushing more aggressively for gender equality to increase fertility.

\section{4. "No" to the means - "No" to using gender equality policies to increase fertility}

The issue of whether governments should push for more gender equality in order to increase fertility raises one fundamental question: Should we link gender equality and fertility policies at all? I have argued in the previous section that gender equality policies designed to influence fertility undermine gender equality aims. Such proposals embody (hidden) andro-centrism, in that they focus primarily on female reproduction.

In the present section, I seek to broaden our perspective on the gender equality/fertility rupture, first by looking at policy/fertility relationships through the lens of gender equality claims and their outcomes; second, by illustrating that the ostensible fertility-raising effects of gender equality are based on distorted perceptions; and, third, by examining the implications that linking gender equality policies to fertility increase would have for gender equality policies. As we will see, the results of these explorations lead us to reject political attempts to link gender equality and fertility policies.

First, the question of whether we should link gender equality and fertility policies at all brings about another question: Which aspects of gender equality are we talking about? The topic of the debate - like most of the political suggestions to promote further gender equality in order to raise fertility - implies that gender equality is a clearly defined, universal concept. Yet a plethora of feminist and gender studies on "sameness" and "difference," on sex vs. gender, and on the intersectionality of sex, gender, class, and ethnicity, have challenged the very assumption of a single unified concept of gender equality. The diversity in the notion of gender equality has also left its imprint on gender equality policies. Women in different countries (and governments of different countries) have pursued quite different strategies, and have taken quite different routes to achieve (greater) gender equality. Regarding the proposed linkage between gender equality and fertility, there have been two main lines of feminist 
argumentation..$^{20}$ Proponents of "maternalism" have based their claims to equality on motherhood, and have requested equality because of women's prime contributions to society as mothers. Egalitarian feminists have rejected claims on the basis of motherhood, arguing that this would lead to inequality. Although any generalization about the impact of these two strategies on gender equality and fertility can easily be countered by pointing to exceptions, there is sufficient comparative evidence to state that countries in which maternalist perspectives have formed the blueprint for gender and for fertility policies are now the countries with low fertility and high gender inequality (e.g., most continental Western European countries). Countries that have endorsed gender equality without looking at its fertility impact are now the countries that enjoy high fertility and high gender equality (e.g., the Nordic countries). These are also the countries that have integrated gender equality into a broader political concept of social rights and of social and economic equality for all, while countries with a "maternalist" history of (gender) policies are also countries where "difference" prevails as an organizing principle of social policies and of society at large.

The call to push for gender equality per se ignores such differences in the conceptualization, understanding, and perspectives of gender equality; and it neglects the legal, social, economic, and gender contexts in which gender equality (and fertility) policies are embedded. Yet the content of gender equality policies and their effects depend on the concepts ingrained in the policies, and on the context in which they are implemented. Concept, content, and context make the balance between gender equality and fertility highly nuanced. Given this complexity, the assumption that "more gender equality will lead to higher fertility" appears to be overly simplistic, and, in its generality, also empirically doubtful.

Second, this assertion can be supported by two examples. First, there is ample evidence from both developing and developed countries that increases in gender equality lower fertility. For example, one of the main assumptions of the Second Demographic Transition is that the increase in women's participation in paid employment, education, and politics; gains in female autonomy; and the weakening of male power in the family lead to lower fertility (van de Kaa 1987). It may well be that pushing for greater gender equality in labor force participation, education, politics, or intra-family power distribution in countries and among groups with high gender inequality in these areas will lead to even lower fertility. Ignoring the gender equality

\footnotetext{
${ }^{20}$ Dividing feminist positions into these two groups grossly oversimplifies the diversity of positions on gender equality which feminist discourse has taken over time, across countries, and within countries. However, depicting the different arguments, strategies, and policy requests of the women's and feminist movements even in such a narrow field as gender equality and fertility would surpass the limits of this paper. I therefore only sketch some main lines roughly, even though this brushes aside all other perspectives on gender equality and fertility.
} 
status, and the context and the directions of gender equality policies, may thus lead to unintended, if not adverse effects.

Moreover, de-contextualized, the proposal to push for gender equality in order to increase fertility suggests that gender equality policies are the main (if not the only) remedy for low fertility. The proposal neglects all other factors which influence fertility development, but which may not be related to gender issues. Structural factors, such as economic crisis, high unemployment, prolonged transition from school to work, increased employment insecurity, or long work hours, have all been found to impair fertility, irrespective of the gender equality status achieved (Blossfeld et al. 2005; McDonald 2006b). These factors will not necessarily be addressed by focusing on gender equality, nor will gender equality policies provide the means necessary to offset these factors.

Second, to push the argument further, I even maintain that we lack convincing empirical proofs that gender equality (or policies supporting gender equality) as such will lead to higher fertility. I disagree with Livia Oláh when she asserts that gender equality fosters higher fertility (Oláh in this debate). To corroborate my argument, I draw on studies similar to those which she mentions, but my interpretations are different from hers. First consider fertility developments in Sweden and Finland in the 1990s. Sweden is commonly recognized as the European country that has the most advanced gender equality policies. Its parental leave policies are geared toward retaining women's attachment to the labor market, and toward making men participate equally in childrearing. These policies are often said to contribute to the high fertility in Sweden. Unfortunately, the facts are not as straightforward as we are led to believe. In the 1990s, Sweden was hit by a severe economic crisis. As a consequence, childbearing intensities fell dramatically. This led to an unprecedented fall of the TFR to an all time low of 1.50 in 1998 and 1999 (Andersson 2000; Andersson 2004). Gender equality policies could not counter the fertility effects of the economic crisis.

By contrast, Finland has been less rigorous than Sweden in its efforts to achieve gender equality in work and care. Between 1985 and 1990, Finland introduced its "child home care allowance" scheme, which widened the gender gaps in employment and care substantially. Under this scheme, the parents of a child below age three who is not in municipal day care are granted a child home care allowance until the child is three years old. Additional means-tested benefits are paid to low and average income families if one parent takes care of the child at home; a sibling increase is paid if other children below age seven in the family do not make use of public child care; and the local municipality can supplement the national benefits. In the early 1990s, the allowance was quite substantial, equaling about the municipal costs of caring for a child in public child care (Sipilä and Korpinen 1998). This was more than most other social benefits, and it was granted on top of other benefits (e.g., unemployment benefits). Although the 
regulations are gender-neutral in their formulation, the child home care allowance is almost exclusively drawn by women, and mostly by women with low levels of education. In the early 1990s, Finland, like Sweden, was hit by a severe economic crisis. Unlike in Sweden, Finnish birth intensities and the TFR did not drop. Researchers attribute this to the child home care allowance (Vikat 2004; Sipilä and Korpinen 1998), which offered women who lost their job or could not find work during the crisis the opportunity to bridge the recession (ibid), so that giving birth became almost a "source of livelihood" during the economic depression (Sipilä and Korpinen 1998:270). We can therefore conclude that a policy which strengthened the gender segregation of work and care, and which made work/care differences among women larger, helped to maintain fertility levels, while gender equality policies were ineffective under tense economic conditions. We may even speculate whether gender equality policies are only good for fertility during good economic times - with the dire prospect that they will be bad for fertility development in Europe when the continent is confronted with rising economic insecurity and persistently high unemployment. This example shows that gender equality policies are not a panacea for all factors which influence childbearing behavior and fertility development.

My second example concerns the uptake of father's parental leave, and the effect of this leave on subsequent childbearing in Sweden. Livia Oláh rightly stressed the positive effects of shared parental leave on fertility in Sweden. Research has indeed shown that couples in which the man takes some parental leave are more inclined to have a second child than couples in which the father does not go on parental leave (Oláh 2003; Duvander and Andersson 2006; Duvander, Lappegård, and Andersson 2010). However, this only applies to fathers who take a marginal share of parental leave, up to $25 \%$ of their yearly income. ${ }^{21}$ If fathers take more parental leave, second birth intensities drop even below those of fathers who do not take any parental leave. Since the majority of fathers do not share parental leave equally with the mother, and since a long paternity leave is associated with a reduction in childbearing intensities, we can state that "gender equality light" (Rønsen and Skrede 2006) may be supportive of childbearing, but "gender equality pure" may not be conducive to further childbearing.

The third argument against linking gender equality and fertility concerns the detrimental consequences which such a connection would have for gender equality. I now consider the relationship from the opposite direction relative to the one taken above, and want to sketch three problems which then arise:

\footnotetext{
${ }^{21}$ The register data used by Duvander and Andersson (2006) and Duvander, Lappegård, and Andersson (2010) did not list the number of parental leave days per year per person; the authors could only calculate the share of income which came from parental leave benefit per year and per person.
} 
First, this relationship makes gender equality policies dependent on (women's and men's) reproductive behavior, and on fertility development. The baseline for gender equality policies would not be equality; instead it would be high fertility levels, whichever way we define "high." In a fertility framework, it is not the democratic obligation to overcome inequality, but the need to entice more women into having more children that legitimates gender equality policies. In reality, the progress made towards gender equality may not matter at all, as long as fertility rates rise to the desired level. This raises several issues: Will gender equality policies be stopped or even reversed if the politically defined satisfactory fertility level is reached, or if fertility turns out not to reach the designated level? Why should women have to have the politically desired number of children in order to attain something they have been fighting to achieve for over 200 years; namely, gender equality? To repeat a previous argument, requesting more procreation from women as a means of getting more gender equality is not a road to equality, but another way to deceive women.

Second, gender equality policies situated within a fertility framework tend to essentialize heterosexuality and to regard women (and men) as a homogenous group. All women and men are perceived as able, willing, and ready to have children. Such an approach ignores differences among women and among men, and it conceals that parenthood is not a state that stretches over the entire life course. The approach also fails to recognize that the conditions and needs for parenthood might vary substantially among different social groups. It discriminates against gays, lesbians, transsexuals, and against all those who cannot or do not want to reproduce. Recognizing differences between individuals ${ }^{22}$ is vital to gender equality policies, as well as to fertility development; thus, any attempt to set aside the recognition of differences by incorporating gender equality into fertility aspirations must be rejected.

Third, subsuming gender equality policies under population policy aims narrows the range of gender equality and of equality policies. There is a danger that the current shift in focus from gender equality to family policy will be further strengthened, and that gender equality policies will be curtailed even further to make room for more family policies, especially if fertility-enhancing goals guide policy formation. ${ }^{23}$ Gender aspects which are supposedly unrelated to fertility risk are not to be touched. This implies that issues such as inequalities in income, career opportunities, or political representation may go unchallenged, as will such gender issues as gendered power, exploitation, and violence; trafficking in women, girls, and boys; sexual discrimination;

\footnotetext{
${ }^{22}$ The recognition of differences includes a critical assessment of which differences have been turned into inequalities (such as female reproduction) and of which public measures can prevent this.

${ }^{23}$ The fact that most examples of positive impacts of gender equality on fertility refer to family policies underlines this limitation.
} 
gendered rights and gendering judicial practices; or androcentrism and sexism in science, values, norms, and practices governing society at large. Gender equality is a value per se. It should therefore be the guiding principle for all political, economic, social, private, and scientific practices, and should not be subsumed under fertilityenhancing aims.

\section{Conclusion}

Our reflections on gender equality and on fertility have demonstrated that we must separate gender equality aims from fertility aspirations, all the more so since the perception that fertility levels are too low, the derived consequences, and the proclaimed panacea, are all based on fictions. There is no doubt that we need gender equality policies, but I strongly question whether we need pronatalist policies, and we certainly do not need such policies in the guise of gender equality. We need gender equality policies which recognize diversity, including in reproductive behaviors, and which tackle inequality based on gender, class, ethnic, social, and sexual differentiation. We need gender equality policies which seek to achieve a democratic society that acknowledges otherness. Such policies help to provide the conditions that will allow all people to live the life they strive for, with or without children; and without impairing their economic and social well-being. We need gender equality policies which transcend Eurocentrism and reach beyond national and European borders. Therefore, we must say "yes" to gender equality policies, but "no" to the goal of increasing fertility, "no" to proposals to push more aggressively in this direction, and "no" to gender equality for pronatalist purposes.

\section{Acknowledgments}

I would like to thank Laura Bernardi and Pascal Hetze for inviting me to the debate. I am grateful to my co-debaters, and to the audience for a stimulating discussion. Many thanks also to the reviewers for their insightful comments, and to Jan Hoem, Gunnar Andersson, Renée Flibotte, und Jana Tetzlaff for their support and assistance. 


\section{References}

Anderson, B. (1991). Imagined Communities. London: Verso.

Andersson, G. (2000). The impact of labour-force participation on childbearing behavior: Pro-cyclical fertility in Sweden during the 1980s and the 1990s. European Journal of Population 16(4): 293-333. doi:10.1023/A:1006454909642.

Andersson, G. (2004). Demographic trends in Sweden: An update of childbearing and nuptiality up to 2002. Demographic Research 11(4): 95-110. doi:10.4054/DemRes.2004.11.4.

Birg, H. (2001). Die demographische Zeitenwende. Bevölkerungsrückgang in Deutschland und Europa. München: Beck'sche Reihe.

Bloom, D., Canning, D., and Fink, G. (2008). Population aging and economic growth. Commission on growth and development. (Working Paper No. 32).

Bloom, D., Canning, D., Fink, G., and Finlay, J. (2010). The cost of low fertility in Europe. European Journal of Population 26(2): 141-158. doi:10.1007/s10680009-9182-1.

Blossfeld, H.-P., Klijzing, E., Mills, M., and Kurz, K. (eds.) (2005). Globalization, Uncertainty, and Youth in Society. New York: Routledge.

Bongaarts, J. (2004). Population aging and the rising costs of public pensions. Population and Development Review 30(1): 1-23. doi:10.1111/j.17284457.2004.00001.x.

Busemeyer, M., Goerres, A., and Weschle, S. (2009). Attitudes towards redistributive spending in an era of demographic ageing: The rival pressures of age and income in 14 OECD countries. Journal of European Social Policy 19(3): 195-212. doi:10.1177/0958928709104736.

Caldwell, J. and Caldwell, P. (1986). Limiting Population Growth and the Ford Foundation Contribution. London: F. Pinter.

Coleman, D. (2006a). Europe's demographic future: Determinants, dimensions, and challenges. In: Demeny, P. and McNicoll, G. (eds.): Population and Development Review 32, Supplement: The Political Economy of Global Population Change, 1950-2050: 52-95. 
Coleman, D. (2006b). Immigration and ethnic change in low-fertility countries: A third demographic transition. Population and Development Review 32(3): 401-446. doi:10.1111/j.1728-4457.2006.00131.x.

Coleman, D. (2009). Divergent patterns in the ethnic transformation of societies. Population and Development Review 35(3): 449-478. doi:10.1111/j.17284457.2009.00293.x.

Commission of the European Communities (2005a). Report from the Commission to the Council, the European Parliament, the European Economic and Social Committee and the Committee on the Regions on equality between women and men, 2005. (Com(2005) 44 final).

Commission of the European Communities (2005b). Communication from the Commission. Green Paper "Confronting demographic change: A new solidarity between the generations". (COM(2005) 94 final).

Connelly, M. (2008). Fatal Misconception. The Struggle to Control World Population. Cambridge, Mass.: The Belknap Press.

Council of Europe (2006). Recent Demographic Developments in Europe 2005. Strasbourg: Council of Europe Publishing.

de Gouges, O. (2003). Déclaration des droits de la femme et de la citoyenne. Paris: Mille et une nuits.

Demeny, P. (1986). Pronatalist policies in low-fertility countries: Patterns, performance, and prospects. Population and Development Review 12, Supplement: BelowReplacement Fertility in Industrial Societies: Causes, Consequences, Policies: 335-358. doi:10.2307/2807916.

Demeny, P. (2003). Population policy dilemmas in Europe at the dawn of the twentyfirst century. Population and Development Review 29(1): 1-28. doi:10.1111/j.1728-4457.2003.00001.x.

Duvander, A.-Z. and Andersson, G. (2006). Gender equality and fertility in Sweden: A study on the impact of the father's uptake of parental leave on continued childbearing. Marriage and Family Review 39(1/2): 121-142. doi:10.1300/J002v39n01 07.

Duvander, A.-Z., Lappegård, T., and Andersson, G. (2010). Family policy and fertility: Fathers' and mothers' use of parental leave and continued childbearing in Norway and Sweden. Journal of European Social Policy 20(1): 45-57. doi:10.1177/0958928709352541. 
Easterlin, R.A. (1978). What will 1984 be like? Socioeconomic implications of recent twists in age structure. Demography 15(4): 397-432. doi:10.2307/2061197.

Ehrlich, P. (1968). The Population Bomb. New York: Ballantine Books.

Feyrer, J. (2007). Demographics and productivity. The Review of Economics and Statistics 89(1): 100-109. doi:10.1162/rest.89.1.100.

Frejka, T., Sobotka, T., Hoem, J.M., and Toulemon, L. (eds.) (2008). Childbearing Trends and Policies in Europe. Demographic Research 19, Special Collection 7, Volume 3.

Gal, S. and Kligman, G. (eds.) (2000). Reproducing Gender: Politics, Publics and Everyday Life after Socialism. Princeton: Princeton University Press.

Gilligan, C. (1982). In a Different Voice. Cambridge, Mass.: Harvard University Press.

Greenhalgh, S. (2003). Science, modernity, and the making of China's one-child policy. Population and Development Review 29(2): 163-196. doi:10.1111/j.17284457.2003.00163.x.

Hodgson, D. (1983). Demography as a social science and policy science. Population and Development Review 9(1): 1-34. doi:10.2307/1972893.

Hoem, J.M. (2008). The impact of public policies on European fertility. Demographic Research 19(10): 249-260. doi:10.4054/DemRes.2008.19.10.

Immergut, E., Anderson, K., and Schulze, I. (eds.) (2006). Handbook of West European Pension Politics. Oxford: Oxford University Press.

Kennelly, I., Merz, S., and Lorber, J. (2001). What is gender? American Sociological Review 66(4): 598-605. doi:10.2307/3088925.

Kertzer, D. and Arel, D. (eds.) (2002). Census and Identity. The Politics of Race, Ethnicity, and Language in National Censuses. Cambridge: Cambridge University Press.

Keyfitz, N. (1992). Seven ways of causing the less developed countries' population problem to disappear - in theory. European Journal of Population 8(2): 149167. doi:10.1007/BF01797550.

Koven, S. and Michel, S. (eds.) (1993). Mothers of a New World. Maternalist Politics and the Origins of Welfare States. New York: Routledge. 
Lindh, T. (2005). Productivity is a system property and need not decrease with the age of the workforce. Vienna Yearbook of Population Research 2005: 7-9. doi:10.1553/populationyearbook2005s7.

Lindh, T. and Malmberg, B. (1999). Age structure effects and growth in the OECD, 1950-1990. Journal of Population Economics 12(3): 431-449. doi:10.1007/s001480050107.

Lindh, T. and Malmberg, B. (2009). European Union economic growth and the age structure of the population. Economic Change and Restructuring 42(3): 159-187. doi:10.1007/s10644-008-9057-1.

Lindh, T., Malmberg, B., and Palme, J. (2005). Generations at war or sustainable policy in ageing societies? The Journal of Political Philosophy 13(4): 470-489. doi:10.1111/j.1467-9760.2005.00233.x.

Lynch, J. and Myrskylä, M. (2009). Always the third rail? Pension income and policy preferences in European democracies. Comparative Political Studies 42(8): 1068-1097. doi:10.1177/0010414009331722.

Malmberg, B. (2006). Global population ageing, migration and European external policies. Final Report. Stockholm: Institutet för Framtidsstudier. http://ec.europa.eu/employment_social/spsi/docs/social_situation/walter_migrati on_fin_rep_en.pdf.

McDonald, P. (2006a). An assessment of policies that support having children from the perspective of equity, efficiency and efficacy. Vienna Yearbook of Population Research 2006: 213-234. doi:10.1553/populationyearbook2006s213.

McDonald, P. (2006b). Low fertility and the state: The efficacy of policy. Population and Development Review 32(3): 401-510. doi:10.1111/j.17284457.2006.00134.x.

McDonald, P. (2008). Very low fertility. Consequences, causes and policy approaches. The Japanese Journal of Population 6(1): 19-23.

Miller, E. and Costello, C.Y. (2001). The limits of biological determinism. American Sociological Review 66(4): 592-598. doi:10.2307/3088924.

Oláh, L. (2003). Gendering fertility: Second birth in Sweden and Hungary. Population Research and Policy Review 22(2): 171-200. doi:10.1023/A:1025089031871.

Pateman, C. (1989). The patriarchal welfare state. In: Pateman, C. (ed.). The Disorder of Women. Democracy, Feminism and Political Theory. Stanford: Stanford University Press: 179-209. 
Presser, H. (1997). Demography, feminism, and the science-policy nexus. Population and Development Review 23(2): 295-331. doi:10.2307/2137547.

Prskawetz, A. and Lindh, T. (eds.) (2007). The Relationship between Demographic Change and Economic Growth in the EU. Forschungsbericht Nr. 32. Vienna: Verlag der Österreichischen Akademie der Wissenschaften.

Risman, B. (2001). Calling the bluff a value-free science. American Sociological Review 66(4): 605-611. doi:10.2307/3088926.

Rønsen, M. and Skrede, K. (2006). Nordic fertility patterns: Compatible with gender equality? In: Ellingsæter, A.L. and Leira, A. (eds.). Politicising Parenthood in Scandinavia. Gender Relations in Welfare States. Bristol: The Policy Press: 5376.

Sanderson, W.C. and Scherbov, S. (2007). A near electoral majority of pensioners: Prospects and policies. Population and Development Review 33(3): 543-554. doi:10.1111/j.1728-4457.2007.00184.x.

Schirrmacher, F. (2004). Das Methusalem-Komplott. München: Karl Blessing Verlag.

Sen, A. (1992). Inequality Reexamined. New York: Oxford University Press.

Sipilä, J. and Korpinen, J. (1998). Cash versus child care services in Finland. Social Policy \& Administration 32(3): 263-277. doi:10.1111/1467-9515.00102.

Skirbekk, V. (2003). Age and individual productivity: A literature survey. Rostock: Max Planck Institute for Demographic Research. (MPIDR working paper WP 2003-028). http://www.demogr.mpg.de/papers/working/wp-2003-028.pdf.

Skirbekk, V. (2005). Population ageing negatively affects productivity. Vienna Yearbook of Population Research 2005: 5-6. doi:10.1553/populationyearbook2005s5.

Skocpol, Th. (1992). Protecting Soldiers and Mothers. The Political Origins of Social Policy in the United States. Cambridge, Mass.: Harvard University Press.

Szreter, S. (1993). The idea of demographic transition and the study of fertility change: A critical intellectual history. Population and Development Review 19(4): 659701. doi:10.2307/2938410.

Udry, R. (2000). Biological limits of gender construction. American Sociological Review 65(3): 443-457. doi:10.2307/2657466.

Udry, R. (2001). Feminist critique uncovers determinism, positivism, and antiquated theory. American Sociological Review 66(4): 611-618. doi:10.2307/3088927. 
Neyer: Rostock Debate, second NO: European governments must be more aggressive for gender equality

Urdal, H. (2006). A clash of generations? Youth bulges and political violence. International Studies Quarterly 50(3): 607-629. doi:10.1111/j.14682478.2006.00416.x.

Van de Kaa, D. (1987). Europe's Second Demographic Transition. Population Bulletin 42(1): 1-59. (First published as Lesthaeghe, R. and van de Kaa, D. J. (1986). Twee Demografische Transities? (Two Demographic transitions?). In: van de Kaa, D.J. and Lesthaeghe, R. (eds.). Bevolking: Groei en Krimp (Population: Growth and Decline). Deventer. Van Loghum Slaterus: 9-24).

Van Parijs, P. (1999). The disenfranchisement of the elderly, and other attempts to secure intergenerational justice. Philosophy \& Public Affairs 27(4): 292-333. doi:10.1111/j.1088-4963.1998.tb00072.x.

Vikat, A. (2004). Women's labor force attachment and childbearing in Finland. Demographic Research SC 3(8):177-212: http://www.demographic-research. org/special/3/8/S3-8.pdf. doi:10.4054/DemRes.2004.S3.8.

Watkins, S.C. (1993). If all we knew about women was what we read in Demography, what would we know? Demography 30(4): 551-577. doi:10.2307/2061806.

Wikander, U., Kessler-Harris, A., and Lewis, J. (eds.) (1995). Protecting Women: Labor Legislation in Europe, the United States and Australia 1880-1920. Urbana: University of Illinois Press.

Wilkoszewski, H. and Muth, E. (2009). Demographic change and the acceptance of population-related policies: A comparison of 13 European countries. Rostock: Max Planck Institute for Demographic Research. (MPIDR Working Paper WP2009-034). http://www.demogr.mpg.de/papers/working/wp-2009-035.pdf.

Wollstonecraft, M. (2004). A Vindication of the Rights of Woman. London: Pinguin Classics, ebook.

Yuval-Davis, N. (1997). Gender \& Nation. London: Sage Publications.

Yuval-Davis, N., Anthias, F., and Kofman, E. (2005). Secure borders and safe haven and the gendered politics of belonging: Beyond social cohesion. Ethnic and Racial Studies 28(3): 513-535. doi:10.1080/0141987042000337867. 